\title{
Dislipidemia dan Obesitas Sentral pada Lanjut Usia di Kota Padang
}

\author{
Sudijanto Kamso*
}

\begin{abstract}
Abstrak
Data-data di rumah sakit maupun di masyarakat menunjukkan penyakit kardiovaskuler yang terdiri dari penyakit jantung koroner, penyakit jantung hipertensi dan stroke adalah penyebab utama kematian pada kelompok lanjut usia Penelitian-penelitian menunjukkan bahwa faktor yang dapat menyebabkan timbulnya penyakit kardiovaskuler tersebut adalah gangguan kadar lemak dalam darah (dislipidemia) dan obesitas sentral.

Berbagai penelitian dibidang penyakit kardiovaskular telah dilakukan, tetapi data mengenai dislipidemia dan obesitas sentral pada lansia Indonesia masih dirasakan kurang. Tujuan utama penelitian ini adalah untuk mengetahui prevalensi dislipidemia dan obesitas sentral, serta faktor-faktor yang berhubungan dengan obesitas sentral pada lansia di Padang, daerah dengan prevalensi penyakit kardiovaskular yang tinggi. Suatu studi cross sectional dilakukan pada 205 lansia di kota Padang sebagai sampel, dengan menggunakan metode multistage random sampling. Pengumpulan data dilakukan dengan wawancara menggunakan kuesioner yang terstruktur, pengukuran antropometri dan tekanan darah serta analisa kadar lemak darah. Studi ini menunjukkan bahwa prevalensi dislipidemia dan obesitas sentral didapatkan cukup tinggi, masing-masing lebih dari $45 \%$ pada populasi studi. Kadar trigliserida darah diatas $200 \mathrm{mg} / \mathrm{dl}$, dan rasio total/HDL kolesterol $\geq 5$, meningkatkan resiko terjadinya obesitas sentral, dengan OR masing-masing 8.5 dan 3.08 . Hasil ini menunjukkan bahwa pemeriksaan rutin kadar lemak darah dan pemeriksaan antropometri sederhana pada lansia perlu dilakukan sebagai pencegahan penyakit kardiovaskular
\end{abstract}

Kata kunci : Dislipidemia, obesitas sentral, lansia

\begin{abstract}
Cardiovascular disease has become the first cause of death among elderly. Many studies on the relationship between dyslipidemia, obesity and cardiovascular disease have been done, but studies investigating prevalence of dyslipidemia and central obesity among the elderly in Indonesia are lacking. Therefore, there is an urgent need to elaborate information on dyslipidemia and central obesity in the Indonesian elderly, which will allow the policy makers to provide appropriate intervention programs against cardiovascular disease. The primary purpose of this study was to observe prevalence of dyslipidemia and central obesity, and also to find independent factors of central obesity among elderly in Padang, area with high prevalence of cardiovascular disease. A cross-sectional study was undertaken in Padang with total sample of 205 elderly using multistage random sampling. Data were collected through interview using structured questionnaires, anthropometric measurements, biochemical blood analysis, and blood pressure measurements. Prevalence of dyslipidemia (hypercholesterolemia and LDL-cholesterolemia) and ratio of total cholesterol to HDL cholesterol $\geq 5$ found in the study was quite high, more than $50 \%$ and $45 \%$ respectively, in the study population both in elderly men and women. Prevalence of central obesity was also quite high in elderly women (46.3\%). This study showed that triglyceride level more than $200 \mathrm{mg} / \mathrm{dl}$ (OR 8.5) and ratio of total/HDL cholesterol $\geq 5$ (OR 3.08 ) increase the risk of having central obesity 8.5 fold and 3.08 fold, respectively. Health education program to elderly group should emphasize the importance of regular check of plasma lipid and simple anthropometric measurement for early detection of cardiovascular disease risk factors.
\end{abstract}

Keywords : Dyslipidemia, central obesity, elderly

*Staf Pengajar Departemen Biostatistik Fakultas Kesehatan Masyarakat Universitas Indonesia, Gd. A Lt. 2 Fakultas Kesehatan Masyarakat Universitas Indonesia, Kampus Baru UI Depok 16424 (e-mail: sudijantokamso@yahoo.com) 
Penyakit utama pada kelompok lanjut usia (lansia) di Indonesia adalah penyakit tulang dan sendi, kardiovaskuler, infeksi saluran pernapasan dan gangguan metabolisme. Data-data di rumah sakit maupun di masyarakat menunjukkan penyakit kardiovaskuler yang terdiri dari penyakit jantung koroner, penyakit jantung hipertensi dan stroke adalah penyebab utama kematian pada kelompok lansia. ${ }^{1}$ Dengan meningkatnya usia, terjadi perubahan komposisi tubuh berupa terjadi peningkatan massa lemak, penurunan massa bebas lemak dan penurunan massa tulang. Secara epidemiologi perubahan komposisi tubuh, khususnya peningkatan proporsi dan distribusi lemak tubuh, akan menyebabkan peningkatan akumulasi lemak sentral di abdomen yang mengakibatkan obesitas abdominal atau obesitas sentral. ${ }^{2}$ Pengukuran obesitas sentral yang paling sederhana dan sering digunakan untuk skrining adalah pemeriksaan antropometri, lingkar perut (LPe). Penilaian obesitas sentral dengan cara antropometri ini, secara klinis dianggap cukup praktis dan valid. 3

Banyak peneliti menyarankan bahwa pemeriksaan LPe sudah cukup untuk menegakkan diagnosis akumulasi lemak visceral di abdomen yang merupakan faktor risiko penyakit jantung koroner (PJK). Populasi Asia termasuk Indonesia, mempunyai bentuk tubuh lebih kecil dari populasi Kaukasus. Hal tersebut berisiko mengalami obesitas abdominal yang lebih tinggi, yaitu IMT nya lebih kecil tetapi LPe nya lebih tinggi. ${ }^{4}$ Berbagai penelitian menunjukkan bahwa faktor lain yang dapat menyebabkan timbulnya penyakit-penyakit kardiovaskuler adalah gangguan kadar lemak dalam darah (dislipidemia). Dislipidemia adalah gangguan atau perubahan pada kadar lemak dalam darah. Gangguan itu dapat berupa peningkatan kadar total kolesterol atau hiperkolesterolemia, penurunan kadar High Density Lipoprotein (HDL), peningkatan kadar Low Density Lipoprotein (LDL), atau peningkatan kadar trigliserida dalam darah (hipertrigliserida). 5

Pada dasarnya, kontrol terhadap dislipidemia dan obesitas sentral akan mencegah atau mengurangi kejadian penyakit kardiovaskuler. Proporsi penyakit kardiovaskuler yang tinggi pada etnik minangkabau diperkirakan berkaitan dengan prevalensi dislipidemia dan obesitas sentral yang tinggi. Melalui studi ini diharapkan dapat diketahui prevalensi dislipidemia dan obesitas sentral di kota Padang, serta faktor-faktor yang berhubungan, sehingga upaya pencegahan penyakit kardiovaskuler dapat dilakukan secara lebih rasional.

\section{Metodologi}

Desain studi yang digunakan pada penelitian ini adalah cross sectional. Populasi penelitian adalah penduduk kota padang yang berusia 55-85 tahun, di kota Padang, yang tampak sehat dan masih dapat berjalan.
Responden berasal dari kelompok lansia yang ada dalam masyarakat, yaitu kelompok lansia yang hidup mandiri atau bersama keluarganya. Jumlah sampel yang ditentukan dengan rumus ukuran sampel minimal untuk disain kros seksional adalah 205 responden yang ditarik dengan metoda multistage random sampling dengan perkiraan design effect $=2$. Pengambilan sampel darah puasa dilakukan pada responden, analisa biokimia dilakukan di Laboratorium Kesehatan Daerah. Pengukuran antropometri dan tekanan darah dilakukan sesuai dengan prosedur standard yang berlaku, sebanyak dua kali pengukuran, dan diambil rata-ratanya untuk analisa selanjutnya. Faktor risiko yang di analisa pada studi ini adalah lingkar perut, kadar total kolesterol darah, LDL kolesterol, HDL kolesterol, triglycerida, indeks massa tubuh, tekanan darah sistolik, tekanan darah diastolic, persentase lemak tubuh, status merokok, indeks aktifitas, asupan energi, asupan lemak dan asupan serat. Metode Dietary 24-hour recall digunakan untuk mengestimasi asupan makanan, dan dianalisa dengan The World Food 2 program. Aktifitas Indeks diukur dengan Baecke Physical Activity Scale. ${ }^{6}$ Penggunaan lingkar perut sebagai parameter obesitas sentral berdasar pada kriteria National Cholesterol Education Program criteria modified for Asians. Pada kriteria ini ditentukan bahwa seseorang dinyatakan mempunyai obesitas sentral bila lingkar perut $\geq 90 \mathrm{~cm}$ pada laki-laki dan $\geq 80 \mathrm{~cm}$ pada wanita. ${ }^{7}$ Analisa regresi logistik berganda, menggunakan SPSS 13 software, digunakan untuk menganalisa faktor risiko yang dominan terhadap obesitas sentral.

\section{Hasil}

Pada penelitian ini didapatkan proporsi responden wanita $(71,7 \%)$ lebih besar daripada pria $(28.3 \%)$. Umur rata-rata responden adalah 64 tahun, responden yang berumur dibawah 65 tahun (53.7\%) lebih tinggi daripada yang berumur diatas 65 tahun $(46.3 \%)$. Pada umumnya responden pria ditemukan berpendidikan lebih tinggi daripada wanita yang sebagian besar adalah ibu rumah tangga. Nilai rata-rata lingkar perut lansia wanita di kota Padang melebihi cut off point obesitas sentral yang ditetapkan NCEP ATP III $(\geq 80 \mathrm{~cm})$ yaitu $81 \pm 13$ $\mathrm{cm}$. Selain itu, rata-rata kadar total kolesterol dan LDL kolesterol yang tinggi pada lansia di kota Padang, baik pada pria dan wanita, yaitu masing-masing lebih dari 235 $\mathrm{mg} / \mathrm{dl}$ dan $165 \mathrm{mg} / \mathrm{dl}$, sementara rasio total kolesterol terhadap HDL kolesterol darah juga tinggi yaitu lebih dari 5. (Lihat Tabel 1)

Lanjut usia yang tinggal di Padang mempunyai prevalensi hiperkolesterolemia (total kolesterol $>240$ $\mathrm{mg} / \mathrm{dl}$ ) yang tinggi pada wanita dan pria, masing-masing $50.9 \%$ dan $65.5 \%$. Prevalensi LDL yang tinggi ( $>160$ $\mathrm{mg} / \mathrm{dl}$ ) sebanyak masing-masing $60.4 \%$ dan $72.4 \%$ pada 
Tabel 1. Rata-rata Kadar Lemak Darah, Tekanan Darah, dan Indikator Antropometri Lansia di Kota Padang

\begin{tabular}{lll}
\hline Variabel & \multicolumn{1}{c}{ Wanita } & Pria \\
\hline Total kolesterol & $235 \pm 46 \mathrm{mg} / \mathrm{dl}$ & $246 \pm 33 \mathrm{mg} / \mathrm{dl}$ \\
LDL kolesterol & $165 \pm 28 \mathrm{mg} / \mathrm{dl}$ & $175 \pm 31 \mathrm{mg} / \mathrm{dl}$ \\
Trigliserida & $106 \pm 46 \mathrm{mg} / \mathrm{dl}$ & $123 \pm 49 \mathrm{mg} / \mathrm{dl}$ \\
HDL kolesterol & $47 \pm 10 \mathrm{mg} / \mathrm{dl}$ & $50 \pm 9 \mathrm{mg} / \mathrm{dl}$ \\
Indeks Massa Tubuh (IMT) * & $23 \pm 5 \mathrm{~kg} / \mathrm{m}^{2}$ & $21 \pm 4 \mathrm{~kg} / \mathrm{m}^{2}$ \\
Lingkar Perut (LPe) & $81 \pm 13 \mathrm{~cm}$ & $78 \pm 10 \mathrm{~cm}$ \\
Lemak Tubuh (\%) & $42 \pm 8$ & $30 \pm 10$ \\
Rasio total / HDL kolesterol & $5.2 \pm 1.6$ & $5.0 \pm 0.9$ \\
Tekanan darah sistolik & $135 \pm 24 \mathrm{~mm} \mathrm{Hg}$ & $132 \pm 22 \mathrm{~mm} \mathrm{Hg}$ \\
Tekanan darah diastolik & $84 \pm 11 \mathrm{~mm} \mathrm{Hg}$ & $83 \pm 12 \mathrm{~mm} \mathrm{Hg}$ \\
\hline
\end{tabular}

$* \mathrm{p}<0.05(\mathrm{t}$ test $)$

Tabel 2. Prevalensi, Dislipidemia, Obesitas dan Hipertensi Lansia di Kota Padang

\begin{tabular}{lll}
\hline Variabel & Wanita & Pria \\
\hline Total kolesterol $\geq 240 \mathrm{mg} / \mathrm{dl}$ & $50.9 \%$ & $65.5 \%$ \\
LDL kolesterol $\geq 160 \mathrm{mg} / \mathrm{dl}$ & $60.4 \%$ & $72.4 \%$ \\
Trigliserida $\geq 200 \mathrm{mg} / \mathrm{dl}$ & $5.7 \%$ & $6.9 \%$ \\
HDL kolesterol $\leq 45 \mathrm{mg} / \mathrm{dl}$ & $43.4 \%$ & $31.0 \%$ \\
Rasio total/ HDL kolesterol $\geq 5$ & $45.3 \%$ & $51.7 \%$ \\
Obesitas sentral * & $46.3 \%$ & $12.1 \%$ \\
Indeks Massa Tubuh $\geq 25 \mathrm{~kg} / \mathrm{m}^{2} *$ & $32.7 \%$ & $13.8 \%$ \\
Hipertensi sistolik $($ sistolik $\geq 140 \mathrm{~mm} \mathrm{Hg})$ & $42.2 \%$ & $39.7 \%$ \\
Hipertensi diastolik (diastolik $\geq 90 \mathrm{~mm} \mathrm{Hg})$ & $47.6 \%$ & $43.1 \%$
\end{tabular}

$* \mathrm{p}<0.05\left(\mathrm{X}^{2}\right.$ test $)$

Tabel 3. Hubungan antara Obesitas Sentral, Rasio Total /HDL Kolesterol dengan Hipertensi Diastolik pada Lansia di kota Padang

\begin{tabular}{|c|c|c|c|c|c|}
\hline Variabel Independent & Katagori & Adjusted OR & $\mathbf{9 5} \% \mathrm{CI}$ & $\mathbf{p}$ & \\
\hline \multirow[t]{2}{*}{ Obesitas sentral } & Normal & & Reference & & \\
\hline & Obese & 3,21 & $1.20-8.63$ & 0.020 & \\
\hline \multirow[t]{2}{*}{ Rasio total/ HDL kolesterol } & $<5$ & & Reference & & \\
\hline & $\geq 5$ & 2.54 & $1.00-6.48$ & 0.05 & \\
\hline Significan model & & & & & 0.003 \\
\hline Persentasi prediksi & & & & & $63.4 \%$ \\
\hline
\end{tabular}

wanita dan pria. Tabel ini juga menunjukkan bahwa proporsi obesitas sentral pada lansia pria dan wanita berbeda secara bermakna. Pada lansia wanita prevalensi obesitas sentral adalah $46.3 \%$, lebih tinggi dibanding lansia pria $(12.1 \%)$. (Lihat Tabel 2$)$

Penelitian ini menemukan obesitas sentral (OR 3.21) dan rasio total/Hdl kolesterol (OR 2,54) berhubungan dengan hipertensi diastolik dengan nilai OR adjasted 3,21 95\% CI OR 1,20-8,63). (Lihat Tabel 3)

Model final (Tabel 4.) menunjukkan bahwa kadar trigliserida (OR 8.48), rasio total/HDL kolesterol (OR 3.08), dan merokok (OR 0.116) merupakan faktor determinan obesitas sentral pada lansia di kota Padang.

\section{Pembahasan}

Peningkatan trigliserida, kolesterol total, LDL serta penurunan kadar HDL sering berhubungan dengan kegemukan. Distribusi lemak regional mempunyai pengaruh penting terhadap faktor risiko penyakit metabolik dan kardiovaskular. Peningkatan akumulasi le- 
Tabel 4. Hubungan antara Kadar Trigliserida, Rasio Total /HDL Kolesterol dan Status Merokok dengan Obesitas Sentral, pada Lansia di Kota Padang

\begin{tabular}{lcll}
\hline Variabel & Adjusted OR & $\mathbf{9 5 \%} \mathbf{C I}$ & $\mathbf{p}$ \\
\hline Kadar trigliserida & & & \\
$<200 \mathrm{mg} / \mathrm{dl}$ & & Reference & \\
$\geq 200 \mathrm{mg} / \mathrm{dl}$ & 8.48 & $0.80-90.1$ & 0.076 \\
Ratio Total/HDL Kolesterol & & Reference & \\
$<5$ & 3.08 & $1.09-6.48$ & 0.03 \\
$\geq 5$ & & & \\
Status merokok & & Reference & \\
Tidak merokok & 0.116 & $0.02-0.60$ & 0.011 \\
Merokok & & & \\
Significan model & & & \\
Persentasi prediksi & & & \\
& & & \\
\end{tabular}

mak visceral adalah faktor risiko terhadap coronary artery disease (CAD), hipertensi, stroke dan type 2 diabetes. 8

Suatu penelitian di Taiwan menyatakan bahwa obesitas sentral merupakan prediksi yang lebih baik dibandingkan dengan IMT dan rasio lingkar pinggang/ panggul, terhadap faktor risiko penyakit. ${ }^{9}$ Meskipun persentase lemak tubuh merupakan parameter yang berguna terhadap general obesity, risiko kesehatan lebih baik dan lebih mudah di prediksi dengan lingkar pinggang. ${ }^{10}$

Tingginya prevalensi penyakit kardiovaskular pada lansia di kota Padang, tampak pada tingginya prevalensi hipertensi diastolik pada lansia wanita dan pria yang melebihi $40 \%$. Demikian pula hiperkolesterolemia prevalensinya cukup tinggi pada lansia di Padang, lebih dari $50 \%$ baik pada wanita maupun pria.

Faktor determinan yang paling berperan terhadap kejadian hipertensi diastolik pada studi ini adalah obesitas sentral (OR 3.21). Pada studi ini ditunjukkan bahwa obesitas sentral pada lansia wanita di Padang cukup tinggi yaitu $46 \%$, sementara pada lansia pria adalah $12 \%$. Dan faktor yang berhubungan dengan kejadian obesitas sentral pada lansia di kota Padang adalah kadar trigliserida (OR 8.5), rasio total/HDL kolesterol (OR 3.1) dan status merokok.

Obesitas sentral berhubungan dengan profil lipid seperti peningkatan kolesterol total, kolesterol LDL, trigliserida dan penurunan kolesterol HDL, yang merupakan pencetus terjadinya aterosklerosis koroner, ${ }^{11}$ peningkatan risiko penyakit kardiovaskuler terjadi bila kedua keadaan tersebut terdapat bersama-sama. ${ }^{12}$

\section{Implikasi di Bidang Kesehatan Masyarakat}

Penanganan dislipidemia hendaknya selalu dimulai dengan diet. Tujuan penanganan dislipidemia adalah mencegah penyakit kardiovaskuler dengan menurunkan kadar kolesterol total dan kolesterol LDL, yaitu dengan menurunkan total kolesterol serum menjadi $<200 \mathrm{mg} / \mathrm{dl}$ dan kolesterol LDL menjadi $<130 \mathrm{mg} / \mathrm{dl}$. Risiko terjadinya penyakit jantung koroner akan meningkat dua kali bila kadar total kolesterol melampaui $250 \mathrm{mg} / \mathrm{dl}$ dan akan meningkat empat kali bila melampaui $300 \mathrm{mg} / \mathrm{dl} .{ }^{13}$ Bila dengan penatalaksanaan diet saja (selama 6 bulan) tidak berhasil, maka baru dipertimbangkan pemberian obat penurun lemak darah. Peran dokter dan ahli gizi selalu penting dalam memberikan motivasi dan dorongan serta menjelaskan tujuan dan prinsip penanganan dislipidemia.

Asupan lemak yang dimakan dalam satu hari dianjurkan kurang dari 25\% total energi/hari, sementara lansia kota Padang asupan lemaknya mencapai hampir 30\% dari total energi/hari. ${ }^{14}$ Ikan yang berlemak dianjurkan untuk dikonsumsi setiap hari. Karena biasanya lemak pada ikan lebih baik daripada lemak sapi atau ayam, karena rasio asam lemak tak jenuh dibanding asam lemak jenuhnya yang tinggi. Makin tinggi rasionya makin besar potensi penurunan kolesterol darahnya. Sementara rasio asam lemak tak jenuh dibanding asam lemak jenuh yang dikonsumsi lansia di kota Padang rendah yaitu 1:3.14 Rasio asam lemak tak jenuh banding asam lemak jenuh yang tinggi dapat diperoleh dengan mengurangi konsumsi lemak hewani (kecuali lemak ikan laut) dan menggantinya dengan minyak nabati yang tidak jenuh seperti yang berasal dari jagung dan kacang kedele. Mengganti konsumsi lemak jenuh hanya dengan karbohidrat memang akan menurunkan LDL tapi dapat meningkatkan trigliserida dan menurunkan HDL kolesterol. Meskipun dampak diet rendah kolesterol terhadap kadar lemak darah baru bisa tampak jelas dalam waktu \pm 3 minggu, tapi dalam prakteknya diperlukan waktu yang jauh lebih lama untuk memperoleh respons yang maksimal yaitu beberapa bulan. Hal ini disebabkan karena pelaksanaan diet merupakan proses yang luas yang mengikutsertakan 
perubahan perilaku. Penelitian-penelitian menunjukkan bahwa pada vegetarian ditemui LDL yang rendah. Hal ini disebabkan juga karena serat yang terdapat dalam buah segar, kacang-kacangan, sayuran dan jenis serealia yang bersifat menurunkan lemak darah. Kebutuhan serat per hari berkisar 20-30 gr, sementara pada lansia di kota Padang asupan seratnya \pm 10 gr sehari. ${ }^{14}$

Aktifitas fisik yang dilakukan secara teratur jelas memperbaiki faktor-faktor risiko yang berhubungan dengan kegemukan. Seorang individu gemuk yang secara fisik aktif, mempunyai kemungkinan sakit dan kematian yang lebih rendah dibanding individu yang berat badannya normal tetapi rendah aktivitas fisiknya. Aktifitas fisik lansia di kota Padang dengan menggunakan metode Baecke, termasuk kategori sedang. ${ }^{14}$ Latihan jasmani aerobik yang teratur minimal 30-45 menit 4 kali seminggu mempunyai pengaruh pada penurunan total plasma kolesterol dan kolesterol LDL, terutama bila diiringi dengan penurunan berat badan.

\section{Kesimpulan}

Pada lansia wanita dan pria di Padang, prevalensi dislipidemia $(>50 \%$ ) dan obesitas $(46 \%)$, cukup tinggi Pemeriksaan lemak darah secara rutin dan pemeriksaan antropometri sederhana perlu dilakukan pada lansia sebab trigliserida, rasio total /HDL kolesterol dan obesitas sentral berhubungan sangat erat dengan peningkatan penyakit kardiovaskular. Penanganan dislipidemia dan obesitas sentral perlu diintensifkan dalam program kesehatan masyarakat dengan semakin meningkatnya prevalensi penyakit kardiovaskular.

\section{Daftar Pustaka}

1. Boedhi-Darmojo R, 1996. Penelitian penyakit kardiovaskular di masyarakat pedesaan. Medika; 6:450-457.

2. Guo $\mathrm{S}$ et al, 1999. Aging, body composition, and lifestyle: the Fels Longitudinal Study. American Journal of Clinical Nutrition; Vol. 70,
No. 3, 405-411

3. Turcato et al, 2000. Waist circumference and abdominal sagittal diameter as surrogates of body fat distribution in the elderly: their relation with cardiovascular risk factors. International Journal of Obesity 24, 1005-1010

4. Kathryn et al, 1998. Abdominal Adiposity and Coronary Heart Disease in Women. JAMA;280:1843-1848.

5. Marmot MG , 1993. Epidemiology of tryglicerides and coronary heart disease. Lancet ; 342 : 781 - 2.

6. Baecke et al, 1982.. A short questionnaire for the measurement of habitual physical activity in epidemiological studies. Am J Clin Nutr;36:936-942

7. National Cholesterol Education Program criteria modified for Asians (NCEP ATP III) Expert Panel on Detection, Evaluation, and Treatment of High Blood Cholesterol in Adults. Executive Summary of the Third Report of the National Cholesterol Education Program (NCEP) Expert Panel on Detection, Evaluation, and Treatment of High Blood Cholesterol in Adults (Adult Treatment Panel III). JAMA. 2001;285:2486 -97.

8. MC Carr et al, 2004. Abdominal obesity and dyslipidemia in the metabolic syndrome: importance of type 2 diabetes and familial combined hyperlipidemia in coronary artery disease risk.J. Clin. Endocrinol. Metab.; 89(6): 2601-7.

9. Huang et al, 2005. Obesity in the elderly and its relationship with cardiovascular risk factors in Taiwan. Obesity;13(1): 170-8.

10. Shen et al, 2006. Waist circumference correlates with metabolic syndrome indicators better than percentage fat. Obesity; 14(4): 727-36.

11. Kannel WB, 2000. Risk stratification in hypertension: new insights from the Framingham Study. Am J Hypertens;13:3S-8S.

12. Zaanchetti A,1994. Hyperlipidemia in the Hypertensive patient.Am J Med; 96:3S - 8S

13. Capurso et al, 1992. Lipid control with low-dosage simvastatin in patients with moderate hypercholesterolemia. An Italian multicentre double-blind placebo- controlled study. Eur Heart J;13:11-16.

14. Kamso S. Nutritional Aspects of hypertension in the Indonesian Elderly. PhD Thesis. SEAMEO-TROPMED. University of Indonesia, 2000 